\title{
Protective effect of phloretin on hyperglycemia mediated oxidative stress in experimental diabetic rats
}

\author{
Nithiya $T$ and Udayakumar $R^{*}$ \\ Post Graduate and Research Department of Biochemistry, Government Arts College (Autonomous), Kumbakonam-612 001, Tamilnadu, India
}

\begin{abstract}
Diabetes mellitus is a chronic metabolic disorder characterized by hyperglycemia which affects all the metabolic pathways. Hyperglycemia mediated oxidative stress plays a key role in diabetic complications. Hence, this study was undertaken to evaluate the protective effect of phloretin on streptozotocin induced diabetic rats. The levels of blood glucose, insulin, lipid peroxidation, enzymatic and non-enzymatic antioxidant status were analysed in diabetic and diabetic with phloretin treated rats. In this study, the significant increase in serum glucose and lipid peroxidative markers like thiobarbituric acid reactive substance (TBARS), lipid hydroperoxides (HP) and conjugated diene (CD) in plasma, liver and kidney were observed in diabetic rats. Reduction in the levels of serum insulin, enzymatic antioxidants superoxide dismutase (SOD), catalase (CAT) and glutathione peroxidase (GPx) and non-enzymatic antioxidants vitamin C, E and reduced glutathione (GSH) were analysed in plasma, liver and kidney of STZ-induced diabetic rats. Oral administration of phloretin to diabetic rats for 45 days significantly reverted back the levels of glucose, insulin, lipid peroxidation, enzymatic and non-enzymatic antioxidants to near normal. The present findings suggest that phloretin treatment in diabetes exerts a protective effect by attenuating hyperglycemia mediated oxidative stress and improve the antioxidant activities. So, the phloretin may be used as food supplements for the treatment of diabetes.
\end{abstract}

\section{Introduction}

Diabetes mellitus is a group of disorders of multiple etiologies resulting from a defect in insulin secretion, insulin action or both. Insulin deficiency in turn leads to chronic hyperglycemia with disturbances in carbohydrate, fat and protein metabolism [1]. The two major types of diabetes mellitus (DM) are insulin dependent (IDDM) - type 1 and non -insulin dependent (NIDDM) -type 2. Type 1 DM is characterized by a specific destruction of the pancreatic $\beta$ cells commonly associated with immune-mediated damage [2]. Individuals with type 2 DM display a gradual change in glucose homeostasis due to insulin resistance and/ or decreased insulin secretion [3]. Sustained hyperglycemia leads to the progressive development of long-term microvascular and macrovascular complications which causes morbidity and mortality among those affected $[4,5]$.

Presently, the number of diabetics across the world exceeds 150 million, which has been predicted to rise $>300$ million by the year 2025 [6], and it might be due to an increase in sedentary lifestyle, consumption of energy rich diet, and obesity [7]. The occurrence of diabetes in urbanized countries is rapidly increasing, and this pandemic disease is one of the most persistent causes of death in developed countries. According to recent studies in India, the number of diabetics would be $84-224$ million by the year 2025 and the most prevalence would be among urban population [8].

Numerous studies have shown that diabetes mellitus is associated with oxidative stress, leading to an increased production of reactive oxygen species (ROS), including superoxide radical $\left(\mathrm{O}^{2-)}\right.$, hydrogen peroxide $\left(\mathrm{H}_{2} \mathrm{O}_{2}\right)$, and hydroxyl radical $\left(\mathrm{OH}^{-}\right)$or reduction of antioxidant defense system [9]. Implication of oxidative stress in the pathogenesis of diabetes mellitus is suggested not only by oxygen free radical generation but also due to non-enzymatic protein glycosylation, auto-oxidation of glucose, impaired antioxidant enzyme, and formation of peroxides [10]. Lipid peroxidation (LPO) is a key marker of oxidative stress. It is a free radical-induced process causing oxidative deterioration of polyunsaturated fatty acids that eventually results in extensive membrane damage and dysfunction [11].

Management of diabetes without any toxic side effects is still a challenge to the medical system. There is an increasing demand by patients to use natural products with anti-diabetic activity, because insulin and oral hypoglycemic agents have so many side effects. Hence, the researchers are searching new treatment for diabetes mellitus without side effects. Recently, plant based treatment has been thought to be effective for the prevention and control of various diseases including diabetes [12].

Antioxidants derived from medicinal plant source are gaining more attention as free radical scavengers as they protect against ROS-induced oxidative stress/damage. Nowadays, natural therapies gain importance as they have been shown to regulate the oxidative complications of diabetes [13]. Antioxidants are used as well-known supportive therapy in the management/treatment of diabetes. Thus, there is an increasing demand for natural products with antidiabetic and antioxidant properties to attenuate induced oxidative stress and its complications [14]. Among the natural products, phloretin compound are attracting the interest because of their beneficial effect. Phloretin has been reported to have pharmacological effects including anti-

Correspondence to: Udayakumar R, Post Graduate and Research Department of Biochemistry, Government Arts College (Autonomous), Kumbakonam - 612 001, Tamilnadu, India, E-mail: udayabiochem@yahoo.co.in

Key words: antioxidants, diabetes, lipid peroxidation, phloretin, hyperglycemia

Received: November 25, 2017; Accepted: December 22, 2017; Published: December 26, 2017 
inflammatory [15], anticarcinogenic [16] and hepatoprotective [17]. The potential of phloretin to trap reactive dicarbonyl species and therefore inhibit the formation of advanced glycation end products (AGEs) has been reported [18]. Hence, the present study was aimed to study the protective effects of phloretin on STZ induced diabetic rats through the evaluation of lipid peroxidation (LPO) products and the activities of enzymatic and non-enzymatic antioxidants in plasma, liver and kidney.

\section{Materials and methods}

\section{Chemicals}

Phloretin and streptozotocin were purchased from Sigma Chemicals Company, St. Louis, Mo. USA. All other chemicals and reagents were of analytical grade and purchased from Himedia Laboratories Pvt. Ltd, Mumbai, India.

\section{Animals}

Male albino rats (Rattus norvegicus) weight ranges between 180$200 \mathrm{~g}$ were used in the present investigation. The animals were housed in standard polypropylene cages and maintained under controlled room temperature and humidity with 12-h light and 12-h dark cycle and were fed with standard diet of known composition and water ad libitum. The animals were acclimatized to the laboratory condition for 2-weeks prior to the start of experiment. The study was approved by the institutional Animal Ethical Committee (BDU/IAEC/2015/NE/42/ Dt.17.03.2015), Bharathidasan University, Tiruchirappalli - 620 024, Tamilnadu, India as per committee for the purpose of control and supervision on experimental animals (CPCSEA) guidelines.

\section{Induction of diabetes mellitus}

Diabetes was induced in overnight fasted experimental rats by a single intraperitoneal injection of STZ $(60 \mathrm{mg} / \mathrm{kg} \mathrm{b.w})$ dissolved in freshly prepared citrate buffer $(0.1 \mathrm{M}, \mathrm{pH} 4.5)$. After five days, the blood glucose was analysed and determined the rats with fasting blood glucose greater than $250 \mathrm{mg} / \mathrm{dl}$ were used in the present study.

\section{Experimental design}

The animals were randomly divided into five groups of six animals in each group. Group I - normal control; Group II - diabetic control; Group III - diabetic rats treated with phloretin ( $25 \mathrm{mg} / \mathrm{kg}$ b.w.); Group IV - diabetic rats treated with phloretin (50 mg/kg b.w.) and Group V diabetic rats treated with glibenclamide $(600 \mu \mathrm{g} / \mathrm{kg}$ b.w.). Phloretin and glibenclamide were given orally to diabetic rats using intragastric tube. No death of the diabetic animals was observed till the end of the study. The initial and final body weight of the rats in each group was recorded. At the end of the experimental period, the animals were deprived of food overnight and sacrificed by cervical decapitation. Blood was collected, plasma and serum was separated for the estimation of various biochemical parameters. Liver and kidney tissues were dissected out, washed in ice-cold saline and used to prepare tissue homogenate using phosphate buffer for the measurement of lipid peroxidation products and the enzymatic and non-enzymatic antioxidants.

\section{Biochemical assays}

\section{Determination of serum glucose and insulin}

Serum glucose was estimated using a commercial kit (Sigma Diagnostics Pvt, Ltd., Baroda, India) by the method of Trinder [19]. Insulin was assayed in serum using a commercial kit by Enzyme Linked Immune Sorbent Assay (ELISA) technique based on the method of Brugi, et al. [20].

\section{Assay of lipid peroxidation products}

The concentration of TBARS in the plasma and tissues was estimated by the method of Niehaus and Samuelsson [21]. Lipid hydroperoxide in the plasma and tissues was estimated by the method of Jiang et al. [22]. Conjugated dienes was assayed by the method of Rao and Recknagel [23].

\section{Determination of enzymatic and non-enzymatic antioxidants}

Superoxide dismutase in plasma and tissues was assayed by the method of Kakkar, et al. [24], catalase in plasma and tissues was determined by the method of Sinha [25], glutathione peroxidase in plasma and tissues was measured by the method of Rotruck, et al. [26], ascorbic acid in the plasma and tissues was estimated by the method of Roe and Kuether [27], vitamin E in plasma and tissues was estimated by the method of Baker et al. [28] and reduced glutathione in plasma and tissues was estimated by the method of Ellman [29].

\section{Statistical analysis}

In the present study, the data were presented as mean \pm SD and subjected to statistical analysis and significance was calculated by one way Analysis of Variance (ANOVA) and the individual comparisons were obtained by Duncan's Multiple Range Test (DMRT). Values are considered statistically significant at $5 \%$ level $(p \leq 0.05)$.

\section{Results}

The levels of blood glucose and insulin in normal and experimental animals were determined and the values are depicted in Table 1 . There was a significant increase in the level of glucose and a significant decrease in serum insulin level was observed in STZ induced diabetic rats compared to normal control rats. Oral administration of phloretin and glibenclamide to diabetic rats significantly decreased the level of blood glucose and significantly increased the level of serum insulin when compared to diabetic untreated rats.

The changes in the level of lipid peroxidative markers like thiobarbituric acid reactive substances (TBARS) were analysed in plasma, liver and kidney of normal control, diabetic and diabetic treated rats and the results were presented in Table 2. Diabetic rats showed significantly elevated levels of TBARS in plasma, liver and kidney of STZ - induced diabetic rats when compared to normal rats. Oral administration of phloretin and glibenclamide to diabetic rats for 45 days tends to bring the levels of TBARS significantly to near normal in plasma, liver and kidney.

Table 3 represents the level of lipid peroxidative marker like hydroperoxides in plasma, liver and kidney of normal control, diabetic and diabetic treated rats. The significantly elevated level of hydroperoxides in plasma, liver and kidney of STZ - induced diabetic rats were observed when compared to normal rats. Treatment with phloretin and glibenclamide to diabetic rats tends to bring the level of hydroperoxides (HP) to near normal.

The level of conjugated diene in plasma, liver and kidney of normal and experimental groups of rats were represented in Table 4. The level of conjugated diene (CD) was significantly increased in diabetic rats, when compared with normal rats. The oral administration of phloretin at $25 \mathrm{mg}$ and $50 \mathrm{mg} / \mathrm{kg}$ b.w and glibenclamide treated diabetic rats showed significantly reduced levels of conjugated diene to near normal in plasma, liver and kidney. 
The changes in the activities of enzymatic and non-enzymatic antioxidants in plasma of normal and experimental group of rats were analysed and the results were showed in Table 5. There was a significant reduction in enzymatic and non-enzymatic antioxidants like superoxide dismutase, catalase and glutathione peroxidise and non-enzymatic antioxidants like Vit E, Vit C and GSH in plasma were observed in STZ - induced diabetic rats when compared to normal rats. Oral administration of phloretin to diabetic rats for 45 days reversed the altered levels of enzymatic and non-enzymatic antioxidants to near normal in plasma.

The activities of enzymatic antioxidants superoxide dismutase, catalase and glutathione peroxidase and non-enzymatic antioxidants Vit E, Vit C and GSH in liver of diabetic and diabetic treated rats were analysed and the results were represented in Table 6. Diabetic rats showed significantly decreased levels of superoxide dismutase (SOD), catalase (CAT), glutathione peroxidase (GPx), Vit E, Vit C and GSH in liver when compared with normal control rats. The altered activities of enzymatic and non-enzymatic antioxidants were brought back to near normal by the treatment with phloretin $(25 \mathrm{mg}$ and $50 \mathrm{mg} / \mathrm{kg} \mathrm{b.w})$ as well as glibenclamide treated diabetic rats.

The enzymatic and non-enzymatic antioxidants like SOD, CAT, GPx, Vitamin E, Vitamin C and reduced glutathione levels in kidney of diabetic and diabetic treated rats were analysed and the results were

Table 1. Effect of phloretin on serum glucose and insulin

\begin{tabular}{|c|c|c|}
\hline Groups & $\begin{array}{c}\text { Glucose } \\
(\mathbf{m g} / \mathbf{d L})\end{array}$ & $\begin{array}{c}\text { Insulin } \\
(\boldsymbol{\mu} \mathbf{U} / \mathbf{m L})\end{array}$ \\
\hline $\begin{array}{c}\text { Group I } \\
\text { Normal control }\end{array}$ & $85.23 \pm 5.96^{\mathrm{b}}$ & $53.21 \pm 1.98^{\mathrm{c}}$ \\
\hline $\begin{array}{c}\text { Group II } \\
\text { Diabetic control }\end{array}$ & $284 \pm 22.68^{\mathrm{a}}$ & $32.25 \pm 1.24^{\mathrm{a}}$ \\
\hline $\begin{array}{c}\text { Group III } \\
\text { Diabetic+Phloretin } \\
(25 \mathrm{mg} / \mathrm{kg} \text { b.w })\end{array}$ & $98 \pm 20.06^{\mathrm{b}}$ & $45.57 \pm 1.35^{\mathrm{b}}$ \\
\hline $\begin{array}{c}\text { Group IV } \\
\text { Diabetic+Phloretin } \\
(50 \mathrm{mg} / \mathrm{kg} \text { b.w })\end{array}$ & $90 \pm 7.28^{\mathrm{b}}$ & $52.65 \pm 1.85^{\mathrm{c}}$ \\
\hline $\begin{array}{c}\text { Group V } \\
\text { Diabetic+Glibenclamide } \\
(600 \mu \mathrm{g} / \mathrm{kg} \text { b.w })\end{array}$ & $97 \pm 20.77^{\mathrm{b}}$ & $51.74 \pm 1.62^{\mathrm{c}}$ \\
\hline
\end{tabular}

Values are expressed as mean $\pm \mathrm{SD}$ of six rats from each group.

Values not sharing a common superscript letter differ significantly at $5 \%$ level $(\mathrm{P} \leq 0.05)$ using Duncan's Multiple Range Test (DMRT)

Table 2. Effect of phloretin on the level of lipid peroxidation product TBARS in plasma, liver and kidney

\begin{tabular}{|c|c|c|c|}
\hline \multirow{2}{*}{ Groups } & \multicolumn{3}{|c|}{ TBARS } \\
\cline { 2 - 4 } & $\begin{array}{c}\text { Plasma } \\
(\mathbf{m M / d L})\end{array}$ & $\begin{array}{c}\text { Liver } \\
(\mathbf{m M} / \mathbf{1 0 0 g})\end{array}$ & $\begin{array}{c}\text { Kidney } \\
(\mathbf{m M} / \mathbf{1 0 0 g})\end{array}$ \\
\hline $\begin{array}{c}\text { Group I } \\
\text { Normal control }\end{array}$ & $0.41 \pm 0.02^{\mathrm{c}}$ & $0.89 \pm 0.06^{\mathrm{c}}$ & $1.32 \pm 0.09^{\mathrm{c}}$ \\
\hline $\begin{array}{c}\text { Group II } \\
\text { Diabetic control }\end{array}$ & $0.78 \pm 0.05^{\mathrm{a}}$ & $3.62 \pm 0.28^{\mathrm{a}}$ & $3.52 \pm 0.24^{\mathrm{a}}$ \\
\hline $\begin{array}{c}\text { Group III } \\
\text { Diabetic+Phloretin } \\
(25 \mathrm{mg} / \mathrm{kg} \text { b.w) }\end{array}$ & $0.53 \pm 0.04^{\mathrm{b}}$ & $1.56 \pm 0.10^{\mathrm{b}}$ & $1.96 \pm 0.14^{\mathrm{b}}$ \\
\hline $\begin{array}{c}\text { Group IV } \\
\text { Diabetic+Phloretin } \\
(50 \mathrm{mg} / \mathrm{kg} \text { b.w) }\end{array}$ & $0.46 \pm 0.03^{\mathrm{c}}$ & $0.96 \pm 0.07^{\mathrm{c}}$ & $1.43 \pm 0.10^{\mathrm{c}}$ \\
\hline $\begin{array}{c}\text { Group V } \\
\text { Diabetic+Glibenclamide } \\
(600 \mu \mathrm{\mu g} / \mathrm{kg} \text { b.w) }\end{array}$ & $0.49 \pm 0.03^{\mathrm{c}}$ & $1.59 \pm 0.11^{\mathrm{b}}$ & $1.57 \pm 0.10^{\mathrm{d}}$ \\
\hline
\end{tabular}

Values are expressed as mean $\pm \mathrm{SD}$ of six rats from each group.

Values not sharing a common superscript letter differ significantly at $5 \%$ level $(\mathrm{P} \leq 0.05)$ using Duncan's Multiple Range Test (DMRT).
Table 3. Effect of phloretin on the level of lipid peroxidation product hydroperoxides in plasma, liver and kidney

\begin{tabular}{|c|c|c|c|}
\hline \multirow{2}{*}{ Groups } & \multicolumn{3}{|c|}{ Hydroperoxides } \\
\cline { 2 - 4 } & $\begin{array}{c}\text { Plasma } \\
(\mathbf{m M} / \mathbf{d L})\end{array}$ & $\begin{array}{c}\text { Liver } \\
(\mathbf{m M} / \mathbf{1 0 0 g})\end{array}$ & $\begin{array}{c}\text { Kidney } \\
(\mathbf{m M} / \mathbf{1 0 0 g})\end{array}$ \\
\hline $\begin{array}{c}\text { Group I } \\
\text { Normal control }\end{array}$ & $11.35 \pm 0.79^{\mathrm{c}}$ & $73.12 \pm 5.11^{\mathrm{c}}$ & $66.35 \pm 4.65^{\mathrm{c}}$ \\
\hline $\begin{array}{c}\text { Group II } \\
\text { Diabetic control }\end{array}$ & $24.74 \pm 1.75^{\mathrm{a}}$ & $110.53 \pm 7.76^{\mathrm{a}}$ & $118.13 \pm 8.28^{\mathrm{a}}$ \\
\hline $\begin{array}{c}\text { Group III } \\
\text { Diabetic+Phloretin } \\
(25 \mathrm{mg} / \mathrm{kg} \text { b.w) }\end{array}$ & $15.05 \pm 1.05^{\mathrm{b}}$ & $86.27 \pm 6.03^{\mathrm{b}}$ & $85.73 \pm 6.00^{\mathrm{b}}$ \\
\hline $\begin{array}{c}\text { Group IV } \\
\text { Diabetic+Phloretin } \\
(50 \mathrm{mg} / \mathrm{kg} \text { b.w) }\end{array}$ & $11.49 \pm 0.80^{\mathrm{c}}$ & $78.59 \pm 5.50^{\mathrm{c}}$ & $72.57 \pm 5.07^{\mathrm{c}}$ \\
\hline $\begin{array}{c}\text { Group V } \\
\text { Diabetic+Glibenclamide } \\
(600 \mu \mathrm{\mu g} / \mathrm{kg} \text { b.w })\end{array}$ & $13.52 \pm 0.94^{\mathrm{d}}$ & $85.35 \pm 5.49^{\mathrm{b}}$ & $78.05 \pm 5.47^{\mathrm{d}}$ \\
\hline
\end{tabular}

Values are expressed as mean \pm SD of six rats from each group.

Values not sharing a common superscript letter differ significantly at $5 \%$ level $(\mathrm{P} \leq 0.05)$ using Duncan's Multiple Range Test (DMRT)

Table 4. Effect of phloretin on the level of lipid peroxidation product conjugated diene in plasma, liver and kidney

\begin{tabular}{|c|c|c|c|}
\hline \multirow{2}{*}{ Groups } & \multicolumn{3}{|c|}{ Conjugated diene } \\
\cline { 2 - 4 } & $\begin{array}{c}\text { Plasma } \\
(\mathbf{m M / d L})\end{array}$ & $\begin{array}{c}\text { Liver } \\
(\mathbf{m M} / \mathbf{1 0 0 g})\end{array}$ & $\begin{array}{c}\text { Kidney } \\
(\mathbf{m M} / \mathbf{1 0 0 g})\end{array}$ \\
\hline $\begin{array}{c}\text { Group I } \\
\text { Normal control }\end{array}$ & $0.82 \pm 0.05^{\mathrm{c}}$ & $72.13 \pm 5.01^{\mathrm{c}}$ & $18.65 \pm 1.32^{\mathrm{c}}$ \\
\hline $\begin{array}{c}\text { Group II } \\
\text { Diabetic control }\end{array}$ & $1.62 \pm 0.13^{\mathrm{a}}$ & $101.05 \pm 7.35^{\mathrm{a}}$ & $43.64 \pm 3.06^{\mathrm{a}}$ \\
\hline $\begin{array}{c}\text { Group III } \\
\text { Diabetic+Phloretin } \\
(25 \mathrm{mg} / \mathrm{kg} \text { b.w) }\end{array}$ & $0.95 \pm 0.06^{\mathrm{b}}$ & $94.70 \pm 7.04^{\mathrm{b}}$ & $29.43 \pm 2.05^{\mathrm{b}}$ \\
\hline $\begin{array}{c}\text { Group IV } \\
\text { Diabetic+Phloretin } \\
(50 \mathrm{mg} / \mathrm{kg} \text { b.w) }\end{array}$ & $0.85 \pm 0.05^{\mathrm{c}}$ & $82.23 \pm 6.53^{\mathrm{c}}$ & $20.18 \pm 1.41^{\mathrm{c}}$ \\
\hline $\begin{array}{c}\text { Group V } \\
\text { Diabetic+Glibenclamide } \\
(600 \mu \mathrm{\mu g} / \mathrm{kg} \text { b.w) }\end{array}$ & $0.86 \pm 0.06^{\mathrm{c}}$ & $87.19 \pm 6.75^{\mathrm{d}}$ & $22.09 \pm 1.52^{\mathrm{c}}$ \\
\hline
\end{tabular}

Values are expressed as mean $\pm \mathrm{SD}$ of six rats from each group.

Values not sharing a common superscript letter differ significantly at $5 \%$ level $(\mathrm{P} \leq 0.05)$ using Duncan's Multiple Range Test (DMRT).

given in Tables 7. Diabetic rats showed decreased levels of enzymatic antioxidants SOD, CAT and GPx and non-enzymatic antioxidants Vitamin E, Vitamin C and reduced glutathione (GSH). Treatment with phloretin and glibenclamide to diabetic rats reversed the changes in enzymatic and non-enzymatic antioxidants to near normal level than the diabetic untreated rats.

\section{Discussion}

Streptozotocin has been widely used for inducing diabetes in experimental animals through its toxic effects on pancreatic $\beta$-cells $[30,31]$. The cytotoxic action of STZ is associated with the generation of ROS causing oxidative damage [32,33]. The cytotoxic activity of STZ is mediated by the inhibition of free radical scavenging enzyme thereby enhancing the production of superoxide radical which can damage pancreatic $\beta$-cell. In addition, the intracellular metabolism of STZ produced nitric oxide that leads to DNA fragmentation and $\beta$-cell necrosis. So, the rate of insulin synthesis is decreased that result a clinical condition known as hyperglycemia [34].

In this study, the diabetic rats were found to have higher glucose levels and lower level of insulin when compared to normal control rats. From the results of the present study, it was observed that the daily administration of phloretin to diabetic rats for 45 days decreased the 
Table 5. Effect of phloretin on enzymatic and non-enzymatic antioxidants in plasma

\begin{tabular}{|c|c|c|c|c|c|c|}
\hline Groups & $\begin{array}{c}\text { SOD } \\
\left(\mathrm{U}^{*} / \mathrm{mL}\right)\end{array}$ & $\begin{array}{c}\mathrm{CAT} \\
\left(\mathrm{U}^{@} / \mathrm{mL}\right)\end{array}$ & $\begin{array}{c}\mathrm{GP}_{\mathrm{x}} \\
\left(\mathrm{U}^{*} / \mathrm{mL}\right)\end{array}$ & $\begin{array}{c}\mathrm{GSH} \\
(\mathrm{mg} / \mathrm{dL})\end{array}$ & $\begin{array}{c}\text { Vit C } \\
(\mathrm{mg} / \mathrm{dL})\end{array}$ & $\begin{array}{c}\text { Vit E } \\
(\mathrm{mg} / \mathrm{dL})\end{array}$ \\
\hline $\begin{array}{c}\text { Group I } \\
\text { Normal control }\end{array}$ & $0.50 \pm 0.03^{\mathrm{c}}$ & $6.94 \pm 0.53^{\mathrm{c}}$ & $0.93 \pm 0.06^{\mathrm{c}}$ & $30.13 \pm 2.13^{\mathrm{c}}$ & $6.80 \pm 0.48^{\mathrm{c}}$ & $2.59 \pm 0.18^{c}$ \\
\hline $\begin{array}{c}\text { Group II } \\
\text { Diabetic control }\end{array}$ & $0.25 \pm 0.01^{\mathrm{a}}$ & $3.90 \pm 0.27^{\mathrm{a}}$ & $0.26 \pm 0.01^{\mathrm{a}}$ & $13.80 \pm 0.92^{\mathrm{a}}$ & $4.87 \pm 0.34^{\mathrm{a}}$ & $0.99 \pm 0.06^{\mathrm{a}}$ \\
\hline $\begin{array}{c}\text { Group III } \\
\text { Diabetic+Phloretin } \\
(25 \mathrm{mg} / \mathrm{kg} \mathrm{b.w})\end{array}$ & $0.37 \pm 0.02^{\mathrm{b}}$ & $4.86 \pm 0.21^{\mathrm{b}}$ & $0.72 \pm 0.05^{\mathrm{b}}$ & $22.70 \pm 1.58^{\mathrm{b}}$ & $5.85 \pm 0.40^{\mathrm{b}}$ & $1.76 \pm 0.08^{b}$ \\
\hline $\begin{array}{c}\text { Group IV } \\
\text { Diabetic+Phloretin } \\
(50 \mathrm{mg} / \mathrm{kg} \mathrm{b.w})\end{array}$ & $0.48 \pm 0.02^{\mathrm{c}}$ & $5.80 \pm 0.44^{\mathrm{c}}$ & $0.86 \pm 0.05^{\mathrm{c}}$ & $27.31 \pm 1.91^{\mathrm{c}}$ & $6.34 \pm 0.44^{\mathrm{c}}$ & $2.52 \pm 0.17^{\circ}$ \\
\hline $\begin{array}{c}\text { Group V } \\
\text { Diabetic }+ \text { Glibenclamide } \\
(600 \mu \mathrm{g} / \mathrm{kg} \mathrm{b.w})\end{array}$ & $0.44 \pm 0.03^{\mathrm{c}}$ & $5.15 \pm 0.40^{\mathrm{c}}$ & $0.80 \pm 0.05^{\mathrm{c}}$ & $27.45 \pm 1.93^{\mathrm{c}}$ & $6.78 \pm 0.47^{\circ}$ & $2.49 \pm 0.16^{\mathrm{c}}$ \\
\hline
\end{tabular}

Values are expressed as mean $\pm \mathrm{SD}$ of six rats from each group.

Values not sharing a common superscript letter differ significantly at $5 \%$ level $(\mathrm{P} \leq 0.05)$ using Duncan's Multiple Range Test (DMRT).

$\mathrm{U}^{*}$ - one unit of SOD is defined as the enzyme concentration, which gives $50 \%$ inhibition of NBT reduction in one minute.

$\mathrm{U}^{@}$ - one unit of CAT is defined as the $\mu$ mol of hydrogen peroxide consumed per minute.

$\mathrm{U}^{\#}$ - one unit of GPx is defined as the $\mu \mathrm{g}$ of glutathione consumed per minute

Table 6. Effect of phloretin on enzymatic and non-enzymatic antioxidants in liver

\begin{tabular}{|c|c|c|c|c|c|c|}
\hline Groups & $\begin{array}{c}\text { SOD } \\
\left(\mathrm{U}^{*} / \mathrm{mg} \text { protein }\right)\end{array}$ & $\begin{array}{c}\text { CAT } \\
\left(\mathrm{U}^{@} / \mathrm{mg} \text { protein }\right)\end{array}$ & $\begin{array}{c}\mathrm{GP}_{\mathrm{x}} \\
\left(\mathrm{U}^{\# / m g} \text { protein }\right)\end{array}$ & $\begin{array}{c}\mathrm{GSH} \\
(\mathrm{mg} / 100 \mathrm{~g})\end{array}$ & $\begin{array}{c}\text { Vit C } \\
(\mu \mathrm{g} / \mathrm{mg} \text { protein })\end{array}$ & $\begin{array}{c}\text { Vit E } \\
(\mu \mathrm{g} / \mathrm{mg} \text { protein })\end{array}$ \\
\hline $\begin{array}{c}\text { Group I } \\
\text { Normal control }\end{array}$ & $9.71 \pm 0.67^{\mathrm{c}}$ & $76.83 \pm 2.89^{\mathrm{c}}$ & $9.65 \pm 0.67^{c}$ & $12.29 \pm 0.86^{\mathrm{c}}$ & $0.83 \pm 0.05^{\mathrm{c}}$ & $5.15 \pm 0.36^{\mathrm{c}}$ \\
\hline $\begin{array}{c}\text { Group II } \\
\text { Diabetic control }\end{array}$ & $5.53 \pm 0.38^{\mathrm{a}}$ & $34.82 \pm 1.57^{\mathrm{a}}$ & $4.26 \pm 0.29^{\mathrm{a}}$ & $7.96 \pm 0.55^{\mathrm{a}}$ & $0.42 \pm 0.02^{\mathrm{a}}$ & $3.82 \pm 0.19^{\mathrm{a}}$ \\
\hline $\begin{array}{c}\text { Group III } \\
\text { Diabetic+Phloretin } \\
(25 \mathrm{mg} / \mathrm{kg} \mathrm{b.w})\end{array}$ & $8.01 \pm 0.56^{b}$ & $65.42 \pm 1.36^{\mathrm{b}}$ & $7.73 \pm 0.44^{b}$ & $10.15 \pm 0.71^{b}$ & $0.60 \pm 0.04^{b}$ & $4.52 \pm 0.21^{b}$ \\
\hline $\begin{array}{c}\text { Group IV } \\
\text { Diabetic+Phloretin } \\
(50 \mathrm{mg} / \mathrm{kg} \mathrm{b.w})\end{array}$ & $9.16 \pm 0.64^{c}$ & $74.85 \pm 1.38^{\mathrm{c}}$ & $9.54 \pm 0.66^{\mathrm{c}}$ & $12.05 \pm 0.84^{\mathrm{c}}$ & $0.82 \pm 0.05^{\mathrm{c}}$ & $5.10 \pm 0.35^{\mathrm{c}}$ \\
\hline $\begin{array}{c}\text { Group V } \\
\text { Diabetic+Glibenclamide } \\
(600 \mu \mathrm{g} / \mathrm{kg} \mathrm{b.w})\end{array}$ & $8.58 \pm 0.60^{b}$ & $65.17 \pm 1.87^{b}$ & $8.95 \pm 0.62^{\mathrm{b}}$ & $11.88 \pm 0.83^{\mathrm{c}}$ & $0.76 \pm 0.04^{\mathrm{d}}$ & $5.07 \pm 0.35^{\mathrm{c}}$ \\
\hline
\end{tabular}

Values are expressed as mean $\pm \mathrm{SD}$ of six rats from each group.

Values not sharing a common superscript letter differ significantly at $5 \%$ level $(\mathrm{P} \leq 0.05)$ using Duncan's Multiple Range Test (DMRT).

$\mathrm{U}^{*}$ - one unit of SOD is defined as the enzyme concentration, which gives $50 \%$ inhibition of NBT reduction in one minute.

$\mathrm{U}^{\varrho}$ - one unit of CAT is defined as the $\mu \mathrm{mol}$ of hydrogen peroxide consumed per minute.

$\mathrm{U}^{\#}$ - one unit of GPx is defined as the $\mu \mathrm{g}$ of glutathione consumed per minute

Table 7. Effect of phloretin on enzymatic and non-enzymatic antioxidants in kidney

\begin{tabular}{|c|c|c|c|c|c|c|}
\hline Groups & $\begin{array}{c}\text { SOD } \\
\left(\mathrm{U}^{*} / \mathrm{mg} \text { protein }\right)\end{array}$ & $\begin{array}{c}\text { CAT } \\
\left(\mathrm{U}^{@} / \mathrm{mg} \text { protein }\right)\end{array}$ & $\begin{array}{c}\mathrm{GP}_{\mathrm{X}} \\
\left(\mathrm{U}^{\# / m g} \text { protein }\right)\end{array}$ & $\begin{array}{c}\mathrm{GSH} \\
(\mathrm{mg} / 100 \mathrm{~g})\end{array}$ & $\begin{array}{c}\text { Vit C } \\
(\mu \mathrm{g} / \mathrm{mg} \text { protein })\end{array}$ & $\begin{array}{c}\text { Vit E } \\
(\mu \mathrm{g} / \mathrm{mg} \text { protein })\end{array}$ \\
\hline $\begin{array}{c}\text { Group I } \\
\text { Normal control }\end{array}$ & $11.84 \pm 0.82^{\mathrm{c}}$ & $45.13 \pm 3.15^{\mathrm{c}}$ & $7.06 \pm 0.49^{c}$ & $9.92 \pm 0.69^{c}$ & $0.92 \pm 0.06^{\mathrm{c}}$ & $3.86 \pm 0.27^{\mathrm{c}}$ \\
\hline $\begin{array}{c}\text { Group II } \\
\text { Diabetic control }\end{array}$ & $6.62 \pm 0.46^{\mathrm{a}}$ & $23.34 \pm 1.63^{\mathrm{a}}$ & $3.86 \pm 0.21^{\mathrm{a}}$ & $3.99 \pm 0.27^{\mathrm{a}}$ & $0.54 \pm 0.03^{\mathrm{a}}$ & $1.30 \pm 0.09^{\mathrm{a}}$ \\
\hline $\begin{array}{c}\text { Group III } \\
\text { Diabetic+Phloretin } \\
(25 \mathrm{mg} / \mathrm{kg} \mathrm{b.w})\end{array}$ & $9.32 \pm 0.65^{b}$ & $32.28 \pm 2.25^{\mathrm{b}}$ & $5.60 \pm 0.39^{b}$ & $7.95 \pm 0.55^{\mathrm{b}}$ & $0.76 \pm 0.05^{\mathrm{b}}$ & $2.12 \pm 0.14^{b}$ \\
\hline $\begin{array}{c}\text { Group IV } \\
\text { Diabetic+Phloretin } \\
(50 \mathrm{mg} / \mathrm{kg} \mathrm{b.w})\end{array}$ & $11.01 \pm 0.77^{\mathrm{c}}$ & $40.07 \pm 2.80^{c}$ & $6.93 \pm 0.48^{\mathrm{c}}$ & $8.85 \pm 0.61^{\mathrm{c}}$ & $0.82 \pm 0.05^{\mathrm{c}}$ & $3.67 \pm 0.25^{\mathrm{c}}$ \\
\hline $\begin{array}{c}\text { Group V } \\
\text { Diabetic }+ \text { Glibenclamide } \\
(600 \mu \mathrm{g} / \mathrm{kg} \mathrm{b.w})\end{array}$ & $9.69 \pm 0.67^{b}$ & $38.91 \pm 2.72^{\mathrm{d}}$ & $6.50 \pm 0.45^{\mathrm{c}}$ & $8.74 \pm 0.61^{\mathrm{c}}$ & $0.80 \pm 0.05^{\mathrm{c}}$ & $2.47 \pm 0.18^{\mathrm{db}}$ \\
\hline
\end{tabular}

Values are expressed as mean $\pm \mathrm{SD}$ of six rats from each group.

Values not sharing a common superscript letter differ significantly at $5 \%$ level $(\mathrm{P} \leq 0.05)$ using Duncan's Multiple Range Test (DMRT).

$\mathrm{U}^{*}$ - one unit of SOD is defined as the enzyme concentration, which gives $50 \%$ inhibition of NBT reduction in one minute.

$\mathrm{U}^{\circledR}$ - one unit of CAT is defined as the $\mu$ mol of hydrogen peroxide consumed per minute.

$\mathrm{U}^{\#}$ - one unit of GPx is defined as the $\mu \mathrm{g}$ of glutathione consumed per minute 
blood sugar and increased the insulin in diabetic treated rats. This may be due to phloretin enhancing glucose uptake on peripheral tissues and inhibiting hepatic gluconeogenesis or inhibiting the absorption of glucose in intestine via stimulation of insulin secretion.

Studies have shown that there is a close relationship between the increase of free radicals, blood glucose and lipid peroxidation (LPO) in the progress of diabetes [35]. Diabetes usually exhibit high oxidative stress due to persistent and chronic hyperglycemia, which thereby depletes the activity of antioxidative defense system and thus promotes free radicals generation [36]. In the present study, the increased lipid peroxidation during diabetes may be due to the inefficient antioxidant system. Autooxidation of unsaturated lipids in plasma and membrane may be produce free radicals. The free radicals could react with polyunsaturated fatty acids in cell membrane which leads to lipid peroxidation [37]. Increased lipid peroxidation impairs membrane functions by decreasing membrane fluidity and changing the activity of membrane bound enzymes and receptors [38]. The present investigation reports a significant increase in lipid peroxidation products such as TBARS, HP and CD in the plasma, liver and kidney of diabetic rats which suggest that peroxidative injury may be due to the toxic effects of ROS produced during lipid peroxidation in STZ-induced diabetic rats. Phloretin treated diabetic rats showed a significant reduction in lipid peroxidation products suggest that phloretin prevent oxidative damage by scavenging chronic hyperglycemia induced free radicals.

SOD protects tissues against oxygen free radicals by catalyzing the removal of superoxide radical, converting it into $\mathrm{H}_{2} \mathrm{O}_{2}$ and molecular oxygen, which both damage the cell membrane and other biological structures. CAT is a heme-containing enzyme which catalyses the decomposition of $\mathrm{H}_{2} \mathrm{O}_{2}$ to water and $\mathrm{O}_{2}$ and thus protect the cell from oxidative damage [39]. GPx plays a central role in the catabolism of $\mathrm{H}_{2} \mathrm{O}_{2}$ and the detoxification of endogenous metabolic peroxides and hydroperoxides which catalyzes GSH [40]. Previous studies reported that oxygen free radicals are generated in STZ-treated beta cells and it is thought that reactive oxygen free radicals may inactivate and reduce SOD, CAT and GPx activities and those antioxidant enzymes plays an important role in protecting cells from oxidative damage [41]. In the present study, low levels of SOD, CAT and GPx activity indicated diabetes induced oxidative stress, and a significant elevation of these enzymatic antioxidant activities was observed in phloretin treated diabetic rats which might be due to its scavenging property. Rajadurai and Prince reported that flavonoids inhibit alterations in mitochondrial lipid peroxides, oxidative defense enzymes like SOD, catalase, GPx and glutathione-S-transferase in rodents [42]. Kanno, et al. [43] reported that naringin increased SOD and catalase activities by up regulating gene expression of SOD and catalase.

Considering the non-enzymatic antioxidants, vitamin $\mathrm{C}$, a hydrophilic antioxidant, has the ability to sequester the singlet oxygen radical, stabilize the hydroxyl radical and regenerate vitamin E back to the active site [44]. Vitamin E, a lipophilic antioxidant, transfers its phenolic hydrogen to a peroxyl free radical of peroxidized polyunsaturated fatty acids, thereby breaking the radical chain reaction and averting the peroxidation of membrane lipids [45].

GSH is the most important antioxidant in most mammalian cells. This ubiquitous tripeptide, $\gamma$-Glu-Cys-Gly, performs many cellular functions. In particular, the thiol containing moiety is a potent reducing agent [46]. Depletion of tissue GSH is one of the primary factors that permit lipid peroxidation. GSH is a chief intracellular redox buffer that functions as a direct free radical scavenger, cosubstate for GPx activity, cofactor for many enzymes and it is also involved in the maintenance of exogenous antioxidants such as vitamin $\mathrm{E}$ and $\mathrm{C}$ in their active sites. The maintenance of normal ratio of GSH to oxidized glutathione requires NADPH. NADPH level is essential for maintaining the oxidized glutathione level. During insulin deficiency, the intracellular NADPH level was decreased therefore decreased the GSH level due to the defective glucose oxidation via pentose phosphate cycle [47]. The notable decline in the key cellular nonenzymatic antioxidant defense system extensively provokes the susceptibility to oxidative stress [48]. In addition, GSH interrelated with vitamin C and $\mathrm{E}$ to recycles the tocopheroxyl radicals to tocopherol. It has been proposed that antioxidants maintain the concentration of GSH may restore the cellular defense mechanisms, block lipid peroxidation and thus protect the tissue against oxidative damage [49]. Increased oxidative stress, resulting from a significant increase in aldehyde products of lipid peroxidation has probably decreased the tissue GSH content [50]. In the present study, decreased level of non-enzymatic antioxidants was observed in plasma, liver and kidney of diabetic rats. The administration of phloretin to diabetic rats significantly reverted back the altered levels of these antioxidants, which revealed that the antioxidant potential of phloretin compound. Phloretin at a dose of 50 $\mathrm{mg} / \mathrm{kg}$ b.w showed a more pronounced effect than $25 \mathrm{mg} / \mathrm{kg}$ b.w.

\section{Conclusion}

In conclusion, phloretin exerts a promising therapeutic value in prevention of diabetes. The antidiabetic effect could be mainly attributed to its antioxidant properties which is showed by its impact on lipid peroxidation along with enhanced the activity of antioxidant defense system in liver and kidney of STZ induced diabetic rats.

\section{Acknowledgements}

The authors are thankful to Dr. G. Archunan, Professor and Head, Department of Animal Science, Bharathidasan University, Tiruchirappalli-620 024, Tamilnadu, India for his help and support in the animal study.

\section{References}

1. Bastaki A (2005) Review - Diabetes mellitus and its treatment. Int J Diab and Metab 13: 111.

2. Zhao Y (2011) Autoimmunity and therapeutic challenges of type 1 diabetes. Transl Med 1: 104-40.

3. Ruhe RC, McDonald RB (2001) Use of antioxidant nutrients in the prevention and treatment of type 2 diabetes. J Am Coll Nutr 20: 363S-369S. [Crossref]

4. Resnick HE, Howard BV (2002) Diabetes and cardiovascular disease. Annu Rev Med 53: 245-267. [Crossref]

5. Fowler MJ (2008) Microvascular and macrovascular complications of diabetes. Clin Diabetes 26: 77-82.

6. King H, Aubert RE, Herman WH (1998) Global burden of diabetes, 1995- 2025 prevalence, numerical estimates, and projections. Diabetes Care 21:1414-31.

7. Eidi A, Eidi M, Esmaeili E (2006) Antidiabetic effect of garlic (Allium sativum L.) in normal and streptozotocin-induced diabetic rats. Phytomedicine 13: 624-629. [Crossref]

8. Ramachandran A, Snehalatha C, Viswanathan V (2002) Burden of type 2 diabetes and its complications-The Indian scenario. Curr Sci 83: 1471-1476.

9. Rahimi R, Nikfar S, Larijani B, Abdollahi M (2005) A review on the role of antioxidants in the management of diabetes and its complications. Biomed Pharmacother 59: 365373. [Crossref]

10. Baynes JW (1991) Role of oxidative stress in development of complications in diabetes. Diabetes 40: 405-412. [Crossref]

11. Pari L, Latha M (2005) Antidiabetic effect of Scoparia dulcis: effect on lipid peroxidation in streptozotocin diabetes. Gen Physiol Biophy 24: 13-26. 
12. Surveswaran S, Zhong Cai Y, Corke H, Sun M (2007) Systematic evaluation of natural phenolic antioxidants from 133 Indian medicinal plants. Food Chem 102: 938-953.

13. Arulselvan P, Subramanian SP (2007) Beneficial effects of Murraya koenigii leaves on antioxidant defense system and ultra-structural changes of pancreatic $\beta$-cells in experimental diabetes in rats. Chem Biol Interact 165: 155-164.

14. Power M, Pratley R (2011) Alternative and complementary treatments for metabolic syndrome. Curr Diab Rep 11: 173-178. [Crossref]

15. Blazso G, Gabor M (1995) Effects of prostaglandin antagonist phloretin derivatives on mouse ear edema induced with different skin irritants. Prostaglandins 50: 161-168.

16. He X, Liu RH (2007) Triterpenoids isolated from apple peels have poten antiproliferative activity and may be partially responsible for apple's anticancer activity. J Agric Food Chem 55: 4366-4370.

17. Ali Reza Ebadollahi Natanzi, Shima Mahmoudian, Bagher Minaeie, Omid Sabzevari (2011) Hepatoprotective activity of phloretin and hydroxychalcones against acetaminophen induced hepatotoxicity in mice. Iran J Pharm Sci 7: 89-97.

18. Shao X, Bai N, He K, Ho CT, Yang CS, et al. (2008) Apple polyphenols, phloretin and phloridzin: new trapping agents of reactive dicarbonyl species. Chem Res Toxicol 21: 2042-2050. [Crossref]

19. Trinder P (1969) Determination of glucose in blood using glucose oxidase with an alternative oxygen acceptor. Anal Clin Biochem 6: 24

20. Brugi W, Briner M, Franken N (1988) One step sand witch enzyme immuno assay for insulin using monoclonal antibodies. Clin Bioche 21: 311 -314.

21. Niehaus WG, Samuelson B (1968) Formation of malondialdehyde from phospholipids arachidonate during microsomal lipid peroxidation. Eur J Biochem 6: 126-130.

22. Jiang ZY, Hunt JV, Wolff SP (1992) Ferrous ion oxidation in the presence of xylenol orange for detection of lipid hydroperoxide in low density lipoprotein. Anal Biochem 202: 384-387.

23. Rao KS, Recknagel RO (1968) Early onset of lipid peroxidation in rat liver after carbon tetrachloride administration. Exp Mol Pathol 9: 271-278.

24. Kakkar P, Das B, Viswanathan PN (1984) A modified spectrophotometric assay of superoxide dismutase. Indian J Biochem Biophys 21: 130-132. [Crossref]

25. Sinha KA (1972) Colorimetric assay of catalase. Anal Biochem 43: 389-394.

26. Rotruck JT, Pope AL, Ganther HE, Swason AB (1973) Selenium: biochemical role as a component of glutathione peroxidase. Science 179: 588-590.

27. Ellman GL (1959) Tissue sulfhydryl groups. Arch Biochem Biophys 82: 70-77. [Crossref]

28. Roe JH, Kuether CA (1943) Detection of ascorbic acid in whole blood and urine through the 2, 4 DNPH derivative of dehydroascorbic acid. J Biol Chem 147: 399-407.

29. Baker H, Frank O, De Angelis B, Feingod S (1980) Plasma tocopherol in man at various times after ingesting free or acetylated tocopherol. Nutr Rep Int 21: 531-536.

30. Bolzan AD, Bianchi MS (2002) Genotoxicity of streptozotocin. Mutat Res 512: 121134. [Crossref]

31. Kumar GPS, Arulselvan P, Kumar DS, Subramanian SP (2006) Anti-diabetic activity of fruits of Terminalia chebula on streptozotocin induced diabetic rats. $J$ Health Sci 52(3): 283-291.

32. Szkudelski T (2001) The mechanism of alloxan and streptozotocin action in B cells of the rat pancreas. Physiol Res 50: 537-546. [Crossref]
33. Zhang W, Zhao J, Wang J, Pang X, Zhuang X, Zhu X (2010) Hypo- glycemic effect of aqueous extract of sea buckthorn (Hippophae rhamnoides L.) seed residues in streptozotocin induced diabetic rats. Phytother Res 24: 228-232.

34. Turk J, Corbett JA, Ramanadham S, Bohrer A, McDaniel ML (1993) Biochemical evidence for nitric oxide formation from streptozotocin in isolated pancreatic islets. Biochem Biophys Res Commun 197: 1458-1464.

35. Reddy SV,Tiwari AK, Kumar US, Rao RJ, Rao JM (2005) Free radical scavenging, enzyme inhibitory constituents from antidiabetic Ayurvedic medicinal plant Hydnocarpus wightiana Blume. Phytother Res 19: 277-281.

36. Kamalakannan N, Prince PSM (2006) Antihyperglycaemic and antioxidant effect of rutin, a polyphenolic flavonoid, in streptozotocin-induced diabetic Wistar rats. Basic Clin Pharmacol Toxicol 98: 97-103.

37. Karthikesan K, Pari L, Menon VP (2010) Combined treatment of tetrahydrocurcumin and chlorogenic acid exerts potential antihyperglycemic effect on streptozotocinnicotinamide-induced diabetic rats. Gen Physiol Biophys 29: 23-30.

38. Arulselvan P, Subramanian SP (2007) Beneficial effects of Murraya koenigii leaves on antioxidant defense system and ultrastructural changes of pancreatic $\beta$-cells in experimental diabetes in rats. Chem Biol Interact 165: 155-164.

39. Al-Shiekh AAM, Al-Shati AA, Sarhan MAA (2014) Effect of white tea extract on antioxidant enzyme activities of streptozotocin-induced diabetic rats. Egypt Acad $J$ Biol Sci 6(2): 17-30.

40. Saravanan G, Ponmurugan P (2013) S-allylcysteine improves streptozotocin-induced alterations of blood glucose, liver cytochrome $\mathrm{P}_{450} 2 \mathrm{E} 1$, plasma antioxidant system and adipocytes hormones in diabetic rats. Int J Endocrinol Metab 11: e10927.

41. Prabakaran D, Ashokkumar N (2013) Protective effect of esculetin on hyperglycemiamediated oxidative damage in the hepatic and renal tissues of experimental diabetic rats. Biochimie 95: 366-373.

42. Rajadurai M, Prince PS (2009) Naringin ameliorates mitochondrial lipid peroxides, antioxidants and lipids in isoproterenol-induced myocardial infarction in Wistar rats. Phytother Res 23: 358-362.

43. Kanno S, Shouji A, Asou K, Ishikawa M (2003) Effects of naringin on hydrogen peroxide-induced cytotoxicity and apoptosis in P388 cells. J Pharmacol Sci 92: 166 170. [Crossref]

44. Padayatty SJ, Katz A, Wang Y, Eck P, Kwon O, et al. (2003) Vitamin C as an antioxidant evaluation of its role in disease prevention. J Am Coll Nutr 22: 18-35. [Crossref]

45. Opara EC (2002) Oxidative stress, micronutrients, diabetes mellitus and its complications. J R Soc Promot Health 122: 28-34. [Crossref]

46. Apel K, Heribert H (2004) Reactive oxygen species: Metabolism, oxidative stress and signal Transduction. Annu Rev Plant Biol 55: 373-399.

47. Maritim AC, Sanders RA, Watkins JB (2003) Diabetes, oxidative stress, and antioxidants: a review. J Biochem Mol Toxicol 17: 24-38. [Crossref]

48. Hasanain B, Mooradian AD (2002) Antioxidant vitamins and their influence in diabetes mellitus. Curr Diab Rep 2: 448-456. [Crossref]

49. Chugh SN, Kakkar R, Kalra S, Sharma A (1999) An evaluation of oxidative stress in diabetes mellitus during uncontrolled and controlled state and after vitamin $\mathrm{E}$ supplementation. J Assoc Physicians India 47: 380-383.

50. Winterbourn CC (1995) Concerted antioxidant activity of glutathione and superoxide dismutase. In: Packer L, Fuchs J (Eds.), Biothiols in Health and Disease, Marcel Dekker Inc., New York, pp. 117-134.

Copyright: (C2017 Nithiya T. This is an open-access article distributed under the terms of the Creative Commons Attribution License, which permits unrestricted use, distribution, and reproduction in any medium, provided the original author and source are credited. 